\title{
Contributions of Foreign Direct Investment of Mining Sector to Economic Development of Zambia. Study of Konkola Copper Mines
}

\author{
Article by John Chenjelani Phiri \\ PhD in Management, Texila American University \\ E-mail: Chenjelanijp@yahoo.com
}

\begin{abstract}
The research was about an assessment on the extent of the contribution of foreign direct investments (FDIs) on the economic development of Zambia in general and Copperbelt in particular by the Konkola Copper Mines (KCM) in Chingola.

The survey findings revealed a positive trend in the magnitude and growth rates of factors that underpin the economic benefits of foreign direct investment in the domestic economy, such as increased employment creation, technology transfer or transfer of skills through on-the-job training, education, Government revenue, export earnings, and other economic multiplier effects and contributions to Gross Domestic Product - GDP averaging K6.2 billion when other companies were included (ZDA report 2013).

Thus, KCM showed a favourable pattern and positive impact of the host economy as well as some negative impact.

The study took into consideration whether liberalisation of the Zambian economy and privatisation succeeded in attracting FDIs to Zambia or not. It also found out factors that had played a role in attracting FDIs, analysed the good and bad effects on the development of the country.

The information was obtained as a result of literature review and from conducting interviews through the administration of questionnaires and personal interviews with 500 respondents

The study also tried to establish the extent to which FDIs alleviated poverty in Zambia through the creation of jobs and infrastructure development especially to the impoverished villagers and the poor living in urban areas.
\end{abstract}

Keywords: Economic Development, Employment Creation, Foreign Direct Investments, Gross Domestic Product, Poverty Alleviation.

\section{Introduction}

It could be argued that Foreign Direct Investments (FDIs) have brought development to the developing nations through the development of infrastructure, introduction of new technology and new business systems; improvement of communication, new work culture, creation of employment and in the case of Zambia included the opening up of new mines. (Morrison 2012, Goldin and Reinert 2012, and Wikipedia January, 2016). However, FDIs also have had negative impact as well on developing nations, for instance in Zambia those included casualisation of the work force, mass redundancies, unsafe working conditions for workers, failure to take on the payment of pension of former employees, contamination of the natural environment and increasing dominance of foreign culture over the host country cultures by those of the investors (Fraser and Lungu 2013, Mercy Corps June, 2014).

The research highlighted findings on FDIs and their contribution and/or impact to the economic development of Zambia by case studying on the Konkola Copper Mines headquartered in Chingola. Since the implementation of the investment legislation and policies, Zambia has faced the challenges of measuring the contribution/impact of direct investment in the country. Measuring the contribution/impact of investment provides a means for the country to assess the impact of economic reforms that were put in place by government since 1991. The reforms were largely aimed at the spreading of both local and foreign investment, which in turn, would fuel further economic growth and development, and reduce poverty levels - Zambia Development Agency. (ZDA report 2007 and 2012). 


\section{Problem being studied}

The rate of job losses in mining sector in the country had increased with subsequent increase of technology and closures brought about as a result of exiting of some FDIs. The global economic crunch only worsened the situation. At the same time the country continued to record high level of FDI inflows in millions of dollars in the past 20 years. Though there had been some significant growth in the economy, it did not reflect in the reduction of poverty among the majority of the Zambians who remained unemployed. (Fraser and Lungu, 2011).

According to the report compiled by Fraser and Lungu 2011, the situation led to over dependency of the majority of society on the over stretched few employed citizens. Further, the Government could not collect enough revenue in the form of taxes on the few who were employed to develop the social sector like education, health, transport and communication. Despite that trend, the Government has continued to encourage and support FDI inflows by providing an enabling (investor friendly) environment through policies in the Zambian economy.

\section{The theoretical background}

The world economies are slowly focussing on the dependence of nations on each other through the exploitation of natural resources. It is a well-known fact that all manufacturing nations need raw materials, which are processed into finished products. The finished products are required by customers found worldwide. FDI is one of the ways of doing business that has made the exploitation and sharing of raw materials possible by both developed and developing nations. FDI is said to be one of the systems that has contributed to the reduction in barriers to cross-border trade and investment in spite of distance, time zones and lead to different nations taking trouble to learn other nations' languages to easy up communication. To some extent FDI leads to regulations to be tailor made to accommodate foreign direct investment in some developing countries. (Goldin and Reinert, 2013).

According to ZDA report (2007/12) Zambia's population was estimated at 15 million people and the country's main economic sectors included mining, agriculture, tourism and manufacturing. However, economic activities in Zambia were still dominated by the mining sector, which for many years has counted for an estimated two thirds of total exports, and also continued to significantly influence the growth of the economy. That was evidenced by the positive economic growth in recent past years due to the revival of mining activities both on the Copperbelt and North Western provinces.

The ZDA report (2007/12) indicated that Zambia's main exported products have traditionally been copper and cobalt, which together accounted for about 63 percent of total earnings. Non-traditional exports (exports other than copper and cobalt) were mainly primary products which included cotton lint, fresh vegetables, fresh flowers, cotton yarn, burley/flue cured tobacco, petroleum products. Others were electricity, cement, fuzzy cotton, seed sugar, copper wires, cables and rods as well as semi-precious /precious stones.

The country's main imports are crude oil, chemicals and machinery, iron, steel and manufactured goods. But it is also noted that Zambia imported most of the products for consumption and industry.

In response to a long-term decline in economic fortunes, the government implemented stabilization and enhanced structural adjustment reforms in the early 1990s, designed to introduce a market-based and private-driven economy in place of the state dominated economic system which was obtaining prior to 1991.The liberalization of the economy saw a significant reduction of tariffs and removal of quantitative restrictions and export taxes. The exchange rate was liberalised and export incentive such as the duty drawback scheme and manufacturing under bond were introduced to encourage exports. The liberalization of the economy also saw both increased privatisation of most state-owned enterprises and private foreign direct investment inflows in the domestic economy. This action brought in new business etiquette and practices in Zambia. 


\section{Corporate profile}

Konkola Copper Mines Plc (KCM) is a leading integrated copper producer in Zambia. KCM was primarily engaged in the exploration for/and, mining, production and sale of copper and copper byproducts. KCM is a subsidiary of Vedanta Resources Plc (Vedanta), a London listed diversified metals and resources group with operations in India, Australia, South Africa, Namibia, Zambia \& Ireland.

The mines in the Copperbelt were initially owned by Anglo American Corporation and Roan Selection Trust. However, in the early 1970s the mines were nationalised. During the subsequent 20year period, the government's ownership of the mines was restructured several times.

In 1991, Zambia reverted to plural politics and the government embarked on an exercise to privatize parastatal companies, including the copper mines. By March 2000, the privatization programme of the largest mining assets was completed. Anglo American reacquired a 51 percent stake in Konkola Copper Mines, which comprised mining operations in Chingola, Chililabombwe and smelting and refining operations at Nchanga in Chingola and Nkana in Kitwe respectively. However, in September 2002, Anglo American withdrew as shareholders of KCM. This left a restructured company whose main shareholders were again government entities, Zambia Consolidated Copper Mines Investment Holdings (ZCCM-IH) and Zambia Copper Investments (ZCI).

In November 2004, Vedanta Resources took a 51 percent stake to become the majority shareholder in the company. In 2008, Vedanta Resources increased its holding in KCM to 79.4 percent. Since its original acquisition, over $\$ 3$ billion has been invested in KCM to upgrade equipment, build new facilities and expand capacity. The investments have increased reserves and resources, and also the life of the mines by over 25 years.

At one time KCM was one of the largest private sector employers with over 16,000 employees. KCM enjoyed a strong relationship with the Zambian government and was a committed partner in improving the economic prospects of the country through operations and other activities. (KCM web site).

\section{The purpose of the study}

The study was an exploratory as it sought to gather a wide range of data and impressions to gain insights and familiarity with the contributions of FDIs to the Zambian economic development in general and Copperbelt in particular.

Also assessed were the challenges and opportunities faced by large companies (multinationals) in the empowerment of locals and job creation in Zambia and thereafter came up with a model suitable to the Zambian situation and made recommendations on how those challenges/opportunities could be addressed.

\section{The rationale of the project}

As a Nation, the great contributions that FDIs have made over the years towards the development of the economy and growth to the Gross Domestic Product is there to be seen. A contribution of $40 \%$ of the GDP is significant to the economy coming from the background of very little capital investment (ZDA report, 2007/12).

The rationale behind the choice of studying FDIs was to assess the contributions of the same with regard to the revamping of the Zambian Economy which would culminate into the development of the nation and improvement of the peoples' livelihood through re-capitalisation of infrastructure, alleviation of poverty and creation of jobs.

The study also meant to investigate whether FDI's contributions were negative or not and if they were, was it worth it to allow foreign investment in the country or revert to nationalisation of mines and other companies? The study also was directed at finding out the causes of Zambia's failure to develop in spite of the inflow of FDIs if that was the case. Could encouraging local manufacturing companies and processing of minerals into finished products be a route that Zambia should follow in future?

\section{Research methodology}

A comprehensive and all-encompassing design was used to collect data for the study. The data collection was conducted through the use of literature review, field work using questionnaire and personal interviews. 
The research was a quantitative and qualitative study which sought to investigate the contribution of FDIs to the economic development in areas where the Konkola Copper Mines Company operates with the view to understanding whether the FDIs are benefiting the locals with empowerment and enhancing the standard of living. In order to carry out the task, the researcher adopted the interpretive philosophy and used structured, semi-structured interviews and direct observation to collect primary data.

The study approach used was the deductive reasoning in that the analysis of information was done from general to specific perspective. In other words, conclusions were drawn from reasons given in the findings as to how Zambia has used FDIs to the betterment of its economy.

Data was collected from both primary and secondary sources. This method of research permitted the use of different data collection methods within the study. According to White (2010) information that is new and original at its date of publication is termed as primary material.

The research followed a case study strategy. According to Robson (2012), a case study as a strategy for doing research involved an empirical investigation of a particular contemporary phenomenon within its real-life context using multiple sources of evidence. A single case study was used for it represented a critical case or, alternatively, an extreme or unique case. On the other hand, multiple case studies could have focused upon the need to establish whether the findings of the first case occurred in other cases and consequently generalisations could be made from those findings. Yin (2003).

The study was exploratory that attempted to answer why the FDIs were failing to secure the muchneeded development. In line with that view, Yin (2003) advised that case study research was appropriate for answering why or how questions about a contemporary set of events over which the investigator had little or no control.

In the case, the researcher had no control on the findings from both the documentary secondary data and the interviews with respondents regarding challenges faced by investors. Therefore, using the case study strategy for the research could be justified.

\section{Sources of data}

Secondary data was collected from documents on foreign direct investment and other information from Ministry of Finance, Zambia Development Agency (ZDA), Central Statistics of Zambia, report on Zambia Copper Mines by Alastair Fraser and Dr. John Lungu and others shown in references.

Sample Frame: The sampling frame of the study included: Konkola Copper Mines, Ministry of Finance - MOF, Zambia Development Agency-ZDA, Ministry of Mines, Ministry of Commerce, Trade and Industry and ZRA and the residents of Chingola, home town of KCM. The sample frame was chosen because it helped in triangulating the data collected as the target was either directly or indirectly affected by the activities of the FDI case study. However, that was a general cluster - categorising respondents into sectors.

Sample Size: The study was conducted on the Copperbelt and Lusaka, involving a sample of organisations broken down as follows:

- Konkola Copper Mines on the Copperbelt (280 employees)

- Supervisory Government organisations (involving 20 employees)

- The Intended Beneficiaries (200 residents)

Sample Selection: The sample size was picked using cluster sampling for both quantitative and qualitative data collection. But the comprehensive sample frame was not available in those researched areas. The basic idea of sampling was to select some of the elements in a population, so that conclusions about the entire population could be drawn (Cooper and Schindler, 2016). The reason why sampling was necessary was because of lower costs, greater accuracy of results, and greater speed of data collection and the availability of population elements.

Research Instruments: The study contained information collected by means of the following instruments and methods; interviews, sampling and electronic i.e. sms or short messaging, e-mail and questionnaire. However, questionnaire was the main instrument used in the study.

Research Analysis: The analysis of data was done using quantitative and narrative methods such as excel software and graphs such as tables and histograms. While qualitative data was analysed using applicable themes. The data analysis tools used were the manual based tallying techniques and computer based aided programs like Microsoft Excel, Microsoft Word, Calculator and the SPSS. 


\section{Research results}

\section{Literature review}

Economic role and Social Functions of ZCCM: According to the report compiled by Fraser and Lungu (2011), the mines transformed the Copperbelt into the most developed area of Zambia. As far back as 1929 the private mining companies provided sanitary, orderly compounds to accommodate employees, food rations for employees on a weekly basis, hospitals in all mining settlements and also recreation clubs for employees. In those early years only, European quarters had added facilities within their homes such as electricity and water.

The report stated that ZCCM provided amenities much wider in scope than those offered during the colonial era, including free education for miner's children, alongside subsidised accommodation and food, electricity, water and transport. The mining companies also managed the environment in the mine townships, maintained the roads and collected refuse as well as providing cafeterias, bars and social clubs all over the mine townships.

They encouraged the growth of economic and social activities dependent on miners' incomes, such as shops, farms to supply food to the mine areas and other industrial activities. Youth Development Schemes helped youths in the compounds identify the skills they could pursue and formalise as careers.

Women's clubs concentrated on home craft. Social casework agencies were charged with investigating social conditions in the townships. By the time privatisation was re-introduced, ZCCM had one or two hospitals at each of its operating division.

The Crisis of the ZCCM Model: The authors observed that major progress was made in the first 10 years of independence, but developments slowed down when the price of copper collapsed after the first oil crisis in 1974. Zambia had to borrow in order to maintain social provision. Following the second oil crisis in 1979, interest rates increased and Zambia found itself in a severe debt crisis. The copper prices continued to fall relative to the price of imports for twenty years and the economy was severely affected. Between 1974 and 1994, per capita income declined by $50 \%$ leaving Zambia the $25^{\text {th }}$ poorest country in the world.

The authors further observed that during the economic crisis, ZCCM was treated as a 'cash cow' that was being milked without corresponding investment in machinery and prospecting ventures and the mines suffered from little investment as had been the case before 1969. With little investment in exploration and drilling and a lack of spares in equipment and machinery, no new mines were opened after 1979. The ore bodies in the mines were found deeper and deeper and the cost of production went up. ZCCM production fell from 750,000 tonnes in 1973 to 250,000 tonnes in 2000 .

\section{Privatisation process in zambia}

The Move to Liberalisation: According to the report, during the 1980s the World Bank and the IMF took advantage of Zambia's massive debts and its inability to fund government revenues from mining income to push the country to adopt economic liberalisation policies. Zambia accepted its first conditional loan from the IMF in 1973/4 and entered its first World Bank structural adjustment programme in 1983. According to the report, the International Financial Institutions (IFIs) had thereafter always tightly policed Zambia's economic policies. In July 1987, facing protests from Zambians against the harshness of the measures put in place by the IFIs government rejected the conditions of its loan and instituted a 'New Economic Recovery Programme' that limited debt-service payments to $10 \%$ of the net export earnings. Zambia's refusal to pay at the IMF's preferred rate resulted in almost all Zambia's donors deciding collectively to starve the country of assistance.

In the meantime, arrears to the IMF continued to pile up and no new money arrived. Within the period of eighteen months the donors had made their point that the price of future support would be compliance with donor priorities. The government decided that it had little choice but to accept reengaging the Bank and the Fund which led to devaluing the currency, decontrolling prices and cutting food subsidies.

Finally, Zambia accepted new adjustment programme in 1989 and donors started coming back to the country. However, it was too late for the ruling party United Nation Independence Party (UNIP). There were repeated food riots in the urban areas of the country, followed by industrial unrest and eventually 
the ruling party lost support from the Zambia Congress of Trade Unions (ZCTU). The unions formed an opposition party, the Movement for Multiparty Democracy (MMD), headed by ZCTU leader Frederick T. J. Chiluba. When the country went to the polls, the MMD won the 1991 elections, came into political power and formed the new government.

Privatisation under the MMD and the role of external aid donors: According to the report, MMD had a manifesto that promised to liberalise the economy and the mineworker's union endorsed privatisation since they believed that that was the only way that could bring in new investment. Unions and MMD both believed that the only way to get the country's collapsed economy back on track was to win the trust of international banks and investors, and that the only way to do that was to accept the donors' demands. Donors brought in aid money and the budget became more than $40 \%$ donor dependent.

A number of economic conditions were attached to the loans given to Zambia. Many of those were attached to the privatisation programme designed to sell 280 parastatal companies. By June 1996, 137 had been sold. Foreign companies bought up the largest and most viable firms with very little profit staying in Zambia. The World Bank focus was on the privatisation of mines right from the start. Zambia's qualification in 1996 for the World Bank's Heavily Indebted Poor Countries (HIPC) initiative played one of the major roles in the privatisation of the mines. It should be remembered that throughout the privatisation period the Zambian government was being encouraged by donors to establish an 'investor friendly' policy regime. That contributed to changes made in 1995 to the Investment Act and the Mines and Mineral Development Act. Finally, the mines were in private hands with drastically reduced mineral royalty at the rate of $3 \%$ of the net back value of the minerals produced.

The Act permitted companies to minimise their income tax returns by allowing deductions for investment in mining. The Act provided relief from paying customs duties on imported machinery and equipment. The Act did not specify the forms of relief involved.

Effects of Privatisation in Zambia Copper Mines: According to the report on the mines in general and Konkola Copper Mines in particular, it seemed people had high expectations after the privatisation of the mines. The writers stated that copper prices steadily rose in 2003 and the value of copper exports increased twofold between 2005 and 2006 reaching US\$2.78 billion. The government and the companies claimed that all benefited from the proceeds from copper. That was not the case in as far as the miners were concerned and their dissatisfaction was clearly demonstrated by voting for the opposition Patriotic Front (PF) in preference to the then ruling party the Movement for Multiparty Democracy during the September 2006 elections throughout the mining areas of the Copperbelt. However, the Movement for Multiparty Democracy won the election country wide.

That was a clear demonstration that the people at the Copperbelt rejected the policies of the government by siding with the opposition party, which was not in favour of the foreign investors whom it accused of exploiting the workforce, increasing corporate taxes and limiting foreign ownership of mines.

The writers continued to state that the companies and the Zambian Government both argued that since 1991, under the supervision of the World Bank and the International Monitory Fund (IMF), Zambia had been transformed from a socialist economy dominated by the state-owned Zambia Consolidated Copper Mines (ZCCM) into a free-market system. Consequently, Zambia had become a favoured recipient country for many rich-country aid donors.

The report stated that there was no doubt that privatisation had brought with it more money in the mining industry. Mines that were threatened with closure had remained open and in addition new mines were opened up. It was also true that production and profits had significantly increased.

According to the report, at the time the communities at the Copperbelt did not seem to trust the government, the mining industry, aid donors and the privatisation system. To express their disappointment and frustration the people on the Copperbelt resorted to strikes, protests and the ballot box. People claimed that they were not seeing developmental gains that they were expecting and additionally no promises made during the privatisation process seemed to be honoured. The people were bitter because they perceived and believed that massive wealth was being generated by the mining companies leaves the country before Zambians could see significant benefits. 
The report seemed to suggest that Zambia being a model of free market economy where government and companies worked together to reduce poverty was not enough in itself. It was being suggested that the investors' major responsibility was to invest the much-needed capital into the mining companies. The investors were being urged to revitalise the regional economy, generate employment for workers and a market for local producers. The writers went on to elaborate on the need by investors to respect the law, health, safety and environmental laws of the country to ensure that their operations did not negatively affect the local people.

Once that was done investors, workers and local communities were supposed to urge government to use the taxes they paid to regulate companies' behaviour, to secure an enabling environment for business and to provide social services such as health, education and infrastructure, for instance roads, railway lines and airports.

The authors seemed to suggest also that government on its part could encourage companies to make voluntary and charitable contributions to support local initiatives in programmes that reflected their belief in corporate social responsibility.

The authors of the report observed that Zambia managed to make companies happy but lamentably failed to collect a sensible share of revenue or to perform its role as an effective regulator, protecting the rights of workers and local communities or as a provider of social services.

Challenges of privatisation: The authors of the report identified six problems of privatisation and its aftermath as they conducted their research at the Copperbelt:

One sided deal: The first point was that Zambia got a raw deal during negotiations under Development Agreements, which resulted in investors being exempted from covering most of ZCCM's liabilities, including pensions for its workers, from paying most taxes and from many national laws, for example on environmental pollution.

Regulation: The second point observed was that the World bank and the International Monitory Fund (IMF) directed rather than advising the Zambian Government well in advance before privatisation instead of using Zambia's dependence on them for aid and debt relief as a weapon to ensure that labour laws were passed or tailored in favour of investors. That could be verified from the Bank and the Fund when they diplomatically ordered the Zambian Government to make itself more attractive than its neighbours and competitive by developing an 'investor-friendly' regulatory regime in order to bring investment to Zambia. That resulted into the Investment and the Mining and Minerals Acts removing many of the controls the state had formerly established on the behaviour of companies.

Casualisation of Human Resource: The third point noticed was that although investments had created some new jobs, there was poor quality in employment in that around $45 \%$ of the workforce in the mines was not on permanent and pensionable contracts. In many mines including Konkola Copper Mines workers were put on rolling, fixed-term contracts on drastically less beneficial terms and conditions. In some cases the jobs were 'contracted-out' to companies that paid; in many cases less than half the monthly wage offered to permanent workers in mines.

Increased Pensioner Poverty: The fourth point was that before privatisation, pensioner poverty existed under ZCCM in view of the fact that pension provision slowly worsened. That was made worse when new investors refused to take on the company's liabilities and passed the same on to the Government to pay. Unfortunately, the Zambian state budget was tight and the state found itself in a difficult situation to finance the payments. That was an indication that privatisation took off on a bad start and thousands of former employees could not get pension payments and some of the cases were still not been settled.

According to the report thousands of the workers were declared redundant. That contributed to the reduction of the mine workforce to one half under the period of five years from 45,000 to 22,000 employees. By 2004 the number of employees increased to 31, 000 though the number of employees at the Copperbelt was $22 \%$ as compared to $6 \%$ nationally.

Absence of Linkages with Local Business: The fifth point observed was that there were high expectations from local business men after privatisation, however many local businesses did not benefit as the new mine owners made linkages to suppliers, manufacturers, and markets outside Zambia. Since the introduction of privatisation to Zambia, local suppliers were unable to compete on quality and price with foreign suppliers. Many local suppliers had lost the business they used to conduct with ZCCM. 
Failure to Provide Social Infrastructure: The sixth and final point noticed was that ZCCM provided jobs, hospitals, schools and a range of social services including HIV/AIDS and malaria awareness and prevention programmes. After privatisation of ZCCM, new owners of the mines did not continue to offer the mentioned facilities and programmes. They concentrated on the core business - mining. They left the provision of social infrastructure to the dictates of free-market ideology to which they believed that those goods and services should be provided either by the local authorities or by market forces.

Lack of medical facilities led to many people at the Copperbelt to die from malaria in 2004 and over $30 \%$ of the population were suffering from malaria in a year. The HIV/AIDS pandemic was also ravaging the workforce in Zambia. According to the report the HIV prevalence rate for the Copperbelt was $22.1 \%$ as compared to $17.8 \%$ nationally at the time. But then many companies re-started antimalarial spraying programmes in areas where their workers and the wider community lived and to develop comprehensive HIV/AIDS policies. Others responded at a rather slow pace.

\section{Fieldwork presentation}

The table below show the responses from the fieldwork on various questions posed to the respondents:

\section{Multiple variables table}

\begin{tabular}{|c|c|c|c|c|c|c|c|c|c|}
\hline \multirow{3}{*}{ SN } & \multirow{3}{*}{$\begin{array}{l}\text { Question Area } \\
\text { Variables } \\
\end{array}$} & \multicolumn{8}{|c|}{ Measuring Variables } \\
\hline & & \multicolumn{2}{|c|}{ Totally Agree } & \multicolumn{2}{|l|}{ Agree } & \multicolumn{2}{|l|}{ Disagree } & \multicolumn{2}{|c|}{ Totally Disagree } \\
\hline & & $\begin{array}{l}\text { Frequenc } \\
\mathbf{y}\end{array}$ & $\%$ & $\begin{array}{l}\text { Frequenc } \\
\mathbf{y}\end{array}$ & $\%$ & $\begin{array}{l}\text { Frequenc } \\
\mathbf{y}\end{array}$ & $\%$ & $\begin{array}{l}\text { Frequenc } \\
\mathbf{y}\end{array}$ & $\%$ \\
\hline 01 & $\begin{array}{l}\text { FDI for Country } \\
\text { Development }\end{array}$ & 310 & $62 \%$ & 100 & $20 \%$ & 70 & $14 \%$ & 20 & $04 \%$ \\
\hline 02 & $\begin{array}{l}\text { Relaxed } \\
\text { Conditions for } \\
\text { FDIs } \\
\end{array}$ & 185 & $37 \%$ & 135 & $27 \%$ & 75 & $15 \%$ & 105 & $21 \%$ \\
\hline 03 & $\begin{array}{l}\text { Mining FDIs } \\
\text { Brought } \\
\text { Development }\end{array}$ & 130 & $26 \%$ & 190 & $38 \%$ & 100 & $20 \%$ & 80 & $16 \%$ \\
\hline 04 & $\begin{array}{l}\text { Benefits of FDIs } \\
\text { to Zambia }\end{array}$ & 340 & $68 \%$ & 100 & $20 \%$ & 40 & $08 \%$ & 20 & $04 \%$ \\
\hline 05 & $\begin{array}{l}\text { FDI Benefits } \\
\text { Ordinary } \\
\text { Zambians }\end{array}$ & 400 & $80 \%$ & 50 & $10 \%$ & 50 & $10 \%$ & 00 & $00 \%$ \\
\hline 06 & $\begin{array}{l}\text { FDI Influence on } \\
\text { Zambian Culture }\end{array}$ & 260 & $52 \%$ & 50 & $10 \%$ & 60 & $12 \%$ & 130 & $26 \%$ \\
\hline 07 & $\begin{array}{l}\text { Same Goods in } \\
\text { Zambia as in } \\
\text { Developed } \\
\text { Countries }\end{array}$ & 320 & $64 \%$ & 140 & $28 \%$ & 20 & $04 \%$ & 20 & $04 \%$ \\
\hline 08 & $\begin{array}{l}\text { FDIs Door to } \\
\text { Global Trade }\end{array}$ & 90 & $18 \%$ & 390 & $78 \%$ & 20 & $4 \%$ & 00 & $00 \%$ \\
\hline 09 & $\begin{array}{l}\text { Contribution of } \\
\text { Zambian } \\
\text { Technology to } \\
\text { World Production } \\
\end{array}$ & 140 & $28 \%$ & 180 & $36 \%$ & 90 & $18 \%$ & 90 & $18 \%$ \\
\hline 10 & $\begin{array}{l}\text { The Relationship } \\
\text { between } \\
\text { Multipartism and } \\
\text { FDIs } \\
\end{array}$ & 250 & $50 \%$ & 130 & $26 \%$ & 100 & $20 \%$ & 20 & $04 \%$ \\
\hline 11 & \begin{tabular}{|l|} 
Global Economic \\
Downturn Vs
\end{tabular} & 110 & $22 \%$ & 260 & $52 \%$ & 90 & $18 \%$ & 40 & $08 \%$ \\
\hline
\end{tabular}




\begin{tabular}{|c|c|c|c|c|c|c|c|c|c|}
\hline & $\begin{array}{l}\text { Zambian } \\
\text { Economy and } \\
\text { FDIs }\end{array}$ & & & & & & & & \\
\hline 12 & $\begin{array}{l}\text { The Effect of the } \\
\text { Political } \\
\text { Environment on } \\
\text { FDIs }\end{array}$ & 130 & $26 \%$ & 250 & $50 \%$ & 100 & $20 \%$ & 20 & $04 \%$ \\
\hline 13 & $\begin{array}{l}\text { The Experiences } \\
\text { and Lessons } \\
\text { Learnt as a Result } \\
\text { of the Inflow of } \\
\text { FDI to Zambia }\end{array}$ & 110 & $19 \%$ & 170 & $23 \%$ & 210 & $56 \%$ & 10 & $02 \%$ \\
\hline 14 & $\begin{array}{l}\text { The Pull Out of } \\
\text { Investors (FDI) in } \\
\text { The Mining } \\
\text { Sector Had Left } \\
\text { Many Zambians } \\
\text { Jobless. }\end{array}$ & 330 & $66 \%$ & 140 & $28 \%$ & 10 & $02 \%$ & 20 & $04 \%$ \\
\hline 15 & $\begin{array}{l}\text { The Effect of the } \\
\text { Pull out on the } \\
\text { Heath Sector in } \\
\text { the Country }\end{array}$ & 240 & $48 \%$ & 220 & $44 \%$ & 20 & $04 \%$ & 20 & $04 \%$ \\
\hline 16 & $\begin{array}{l}\text { Lack of } \\
\text { Employment and } \\
\text { Retrenchments' } \\
\text { Effects on } \\
\text { Education }\end{array}$ & 280 & $56 \%$ & 160 & $32 \%$ & 40 & $08 \%$ & 20 & $04 \%$ \\
\hline 17 & $\begin{array}{l}\text { Many Girls in the } \\
\text { Mining Towns } \\
\text { Turned to } \\
\text { Prostitution as a } \\
\text { Means of Survival }\end{array}$ & 300 & $60 \%$ & 100 & $20 \%$ & 60 & $12 \%$ & 40 & $08 \%$ \\
\hline
\end{tabular}

Source: Fieldwork 2018

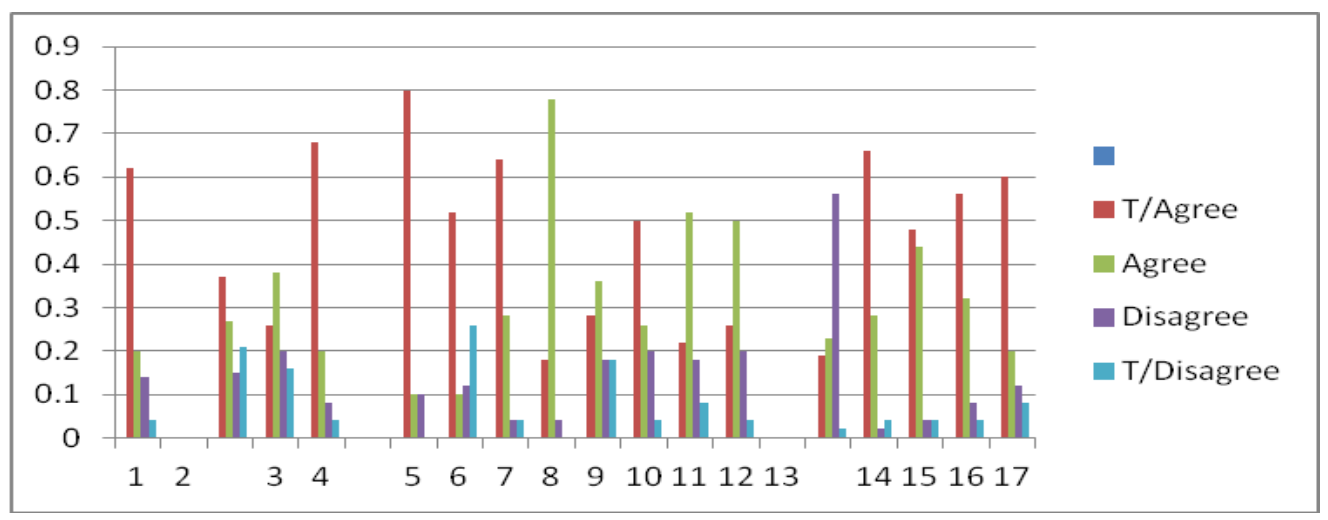

SN01- 17: Rankings on the multiple variable tables

Development in Zambia attributable to FDI: It was suggested that FDI had brought development through increased job creation and poverty reduction in Zambia. The respondents answer as shown in SN01 of multiple tables where 310 totally agreed and 100 agreed that FDI brought development to countries that encourage it and to Zambia in particular. That was $82 \%$ all together.

Relaxed Entry Conditions to Attract Foreign Direct Investment in the Country: SN02 suggested that the Zambian Government had relaxed most entry conditions in order to stimulate or attract FDI in 
the country. The study indicated 185 respondents totally agreed and 135 agreed. Thus $64 \%$ of the respondents seemed to have agreed on the relaxed conditions.

FDIs in the Mining Sector and Development: From Table SN03, 130 respondents totally agreed and 190 agreed that coming of FDI was an effective tool in bringing about development in the country and increases recapitalization of mining industry for Konkola Copper Mine in particular. While 100 respondents were in disagreement to the fact that the encouragement of FDI did contribute to the development of the country and 80 totally disagreed.

Benefits of FDIs to Zambia: 340 respondents totally agreed and 100 agreed that FDI had a positive contribution on the Zambian society and economic growth recapitalization, foreign exchange stability, and technology transfer and improved quality of life through job creation. (SN04)

FDI Benefits Ordinary Zambians: From SN05; 400 respondents totally agreed that the rural Zambian had benefited through investments in mining and other sectors that were based in rural areas. Only 50 respondents disagreed. It was found that $80 \%$ of the inhabitants on the Copperbelt were employed by the mining sector. Konkola Copper Mine being the largest employer in that region of Zambia. It could further be emphasized that FDIs had been a major source of employment in all the mining towns of Zambia. Applying the rule of thumb, it was concluded that investment through FDIs had been a source of job creation in Zambia.

FDI Influence on Zambian Culture: SN06 showed that 260 respondents totally agreed that FDIs had a positive influence on the Zambian culture that advocates for higher learning and exchange of technology there by bringing about less illiteracy. It could be concluded that FDI was indeed a catalyst in brining or reducing illiteracy but as to other form of cultural behaviours, further research needed to be carried out.

While 130 of the respondents totally disagreed to this fact.

Goods in Zambia Same as in Developed Countries: It was suggested that most but not all goods found in developed countries were similar to those found in developing countries. SN07 shows that 320 totally agreed and 140 agreed that similarities in goods produced in developed countries were very minimal while a total of 40 respondents were in disagreement to that fact.

FDIs Opened Doors for Zambia to Global Trade: Export had increased over the past years and that had increased foreign exchange earning thereby bring a balance demanded on exchange rates as 390 respondents also agreed that mining in the country had contributed to an increase in global trade in the country. Thus, coming of multinational companies in the mining resulted in huge export earnings, which contributed positively to the economy. 
Zambia's Technological Contribution to Production: SN09 indicated that 140 respondents totally agreed and 180 agreed that Zambia had not done very well in terms of producing components useful to other countries and 90 totally disagreed to the fact that Zambia had not been proactive in as far as component production was concern.

The Relationship between Multipartism and FDIs: From the data tabulated 250 respondents totally agreed that there was a close relationship between Multipartism and Foreign Direct Investment and also 130 respondents agreed to this fact while, 120 respondents disagreed with the assertion. It was hypothesized that Multipartism tends to promote private sector driven economies hence the encouragement of FDIs to foster investment in the country.

Global Economic Downturn Vs Zambian Economy and FDIs: SN11 indicated that 370 respondents either totally agreed or agreed that the mines were severely affected by the global downturn. Only 130 respondents totally disagreed and totally disagreed to that suggestion. The data values indicated that $74 \%$ agreed to such an assumption and for that reason it could be concluded that the mining sector was adversely affected by that global economic downturn due to huge loss of business which led to severe job losses and closures.

The Effect of the Political Environment on FDIs: As seen from SN12, 130 respondents totally agreed that the political arena had been very conducive for the inflow of Foreign Direct Investment. While 250 respondents agreed that the environment was conducive for FDIs and 20 respondents totally disagreed and 100 respondents disagreed with the hypothesis. ZDA's investment centre had recorded $75 \%$ inflow funds since introduction of multi-party politics.

The Experiences and Lessons Learnt as a Result of the Inflow of FDI to Zambia: SN13 above indicated that 110 respondents totally agreed that there were many lessons to be learnt from FDI while only 170 agreed and supported that thought. While 210 respondents disagreed and 10 totally disagreed with such ideas. Thus, it was observed that FDI had positive effect in creating jobs, there were as well negative effects in Zambia for example job losses through retrenchments, environmental degradation and casualisation of workers.

The Pull Out of Investors (FDIs) in The Mining Sector Had Left Many Zambians Jobless: As can be seen from SN14, 330 totally agreed and 140 agreed that the pull out of investors had negative effect on employment. 10 totally disagreed and 20 disagreed with the hypothesis that the workforce had lost employment as a result of the pullout of some investors in the mining sector. The data values from the table above indicated that that was the case and could be concluded that the pullout of most investors in the mining sector (including Konkola Copper Mine) had a negative effect on the local economy which also resulted in retrenchments.

The Effect of the Pull out on the Heath Sector in the Country: SN15 above showed that 240 totally agreed that withdraws of investment led to job losses and ultimately increased poverty among the citizens of Zambia in general and Copperbelt in particular, for example Luanshya. 220 respondents agreed also to the fact that families would not be able to afford health facilities.

Lack of Employment and Retrenchments' Effects on Schooling: SN16 depicted that 280 totally agreed and 160 agreed that the pull out of investors had negative effect on employment. Thus 56\% of the respondents totally agreed that lack of employment and retrenchments adversely affected the turn out of school going children in the mining town of Chingola because parents had no money to pay school fees. Also $32 \%$ respondents agreed to that fact.

Many Girls in the Mining Towns Turned to Prostitution as a Means of Survival: From SN17 above it could be observed that 300 of the respondents totally agreed that many girls in mining towns turned to prostitution as a means of survival. In addition 100 respondents agreed also to that fact. Of those respondents 40 totally disagreed and 60 disagreed with that statement.

\section{Discussion and Interpretation of the Findings}

The Role FDIs Play in Zambia since the Liberalization of the Economy: According to the literature review findings, FDIs has been in existence for a long time though confined to Organisation for Economic Co-operation and Development (OECD) countries in the early days but has since spread globally and its stocks add up to $28 \%$ of global Gross Domestic Product. 
Factors like strong economy, strong corporate profits and cash flow, a booming stock market and strong currency made developed countries to be in the lead in the provision of FDI outflows.

Foreign Direct Investment (FDI) brought about development to developing nations through the development of infrastructure, introduction of new technology and new business systems, improvement of communication, new work culture, creation of employment and in the case of Zambia including opening of new mines. Others included combating of corruption by the host country, streamlining procedures, investing in the physical and human capacities that were a foundation for both foreign and domestic investments and profits made as a result of FDIs contribution to corporate tax revenues in the host country.

On the other hand FDI has got negative impact also on developing nations, like Zambia casualisation of the work force, mass redundancies, unsafe working conditions for workers, failure to take on the payment of pension to former employees, contamination of the natural environment and increasing dominance of foreign culture over the host country cultures by those of the investors. Others included manipulation by guest countries of the prices of intra-firm trade by multinational enterprises (MNEs) to reduce their global tax payments.

Reasons Why Developed Countries Invested in Zambia through FDIs: In some countries, USA in particular, perceived FDIs as a way of depriving the employees of their jobs through exporting the same abroad.

In Zambia the situation was favourable for the rapid growth of the copper industry due to good world copper prices through the late 1960s and early 1970s. Zambia was seen as the model for a continent moving rapidly towards political and economic independence, industrialisation, creation of employment and an end to poverty. Under ZCCM mining companies managed the environment in the mine townships maintained the roads and collected refuse as well as providing cafeterias, bars and social clubs all over the mine townships.

Nationalisation of the mines in Zambia eventually resulted in the failure by the government to recapitalise the mines. The drop in the price of copper on the world market worsened the situation. Zambia borrowed in order to maintain social provision but eventually found itself in a severe debt crisis. Between 1974 and 1994, per capita income declined by 50\% leaving Zambia the $25^{\text {th }}$ poorest country in the world. Zambia tried to negotiate the interest on loans obtained from World Bank and IMF, but they could not accept the proposal of paying 10\% interest on net export earnings, World Bank and IMF and almost all Zambia's donors decided collectively to starve the country of assistance.

Zambia had little choice but to accept re-engaging the Bank and the Fund. Finally, Zambia accepted new adjustment programme in 1989 and donors started coming back to the country. A number of economic conditions were attached to the loans given to Zambia one of them was to sell 280 parastatal companies and by June 1996, 137 were sold to foreign companies.

When the Movement for Multiparty Democracy (MMD) came into political power in 1991, it liberalised the economy of Zambia. After the liberalisation of the economy donors brought in aid money and the budget became more than $40 \%$ donor dependent. The notables were that:

- Zambia got a raw deal during negotiations under Development Agreements, which resulted in investors being exempted from covering most of ZCCM's liabilities.

- World Bank and the International Monitory Fund (IMF) directed rather than advising the Zambian Government on privatisation, using Zambia's dependence on them for aid and debt relief as a weapon to ensure that labour laws were passed or tailored in favour of investors.

- Although investments had created some new jobs, there was poor quality in employment in that around $45 \%$ of the workforce in the mines was not on permanent and pensionable contracts.

- Investors refused to take on the company's liabilities, instead passed them on to the Government to pay for example pension provision.

- Many local suppliers lost the business they used to conduct with ZCCM.

- New investors left the provision of social infrastructure (like schools and hospitals) to the dictates of free-market ideology that those goods and services should be provided either by the local authorities or by market forces.

Conditions Given to Zambia for it to Receive Foreign Direct Investment: World Bank focus was on the privatisation of the mines right from the start. Zambia's qualification in 1996 for the World 
Bank's Heavily Indebted Poor Countries (HIPC) initiative played one of the major roles in the privatisation of the mines. Throughout the privatisation period the Zambian government was being encouraged by donors to establish an 'investor friendly' policy regime. Finally, the mines were in private hands with drastically reduced mineral royalty at the rate of $3 \%$ of the net back value of the minerals produced.

After the liberalisation of the economy copper prices steadily rose in 2003 and the value of copper exports increased two-fold between 2005 and 2006 reaching US $\$ 2.78$ billion, but the benefits from the proceeds of copper did not trickle down to workers who showed their dissatisfaction by voting for the opposition party (Patriotic Front - PF) during the September 2006 general elections though the Movement for Multiparty Democracy won the election country wide. Zambia had managed to make companies happy but had lamentably failed to collect a sensible share of revenue or to perform its role as an effective regulator, protecting the rights of workers and local communities or as a provider of social services.

To attract FDIs, Zambia undertook legislative reforms to improve the investment climate, which led to the enactment, revision and amendments of pieces of legislation, for example the Zambia Development Act, Companies Act and the Employment Act. To stimulate private sector investment in the country, the Zambian government implemented the IMF and World Bank reform programmes, which led to the abolition of price controls, liberalisation of interest rates, abolition of exchange rate controls, $100 \%$ repatriation of profits, free entry to investment in virtually all sectors of the economy, privatisation of state-owned enterprises, trade reforms aimed at simplifying and harmonizing the tariff structure and removal of quantitative restrictions on imports.

The Benefits of Foreign Direct Investment to Zambia: The economic benefits of both local and foreign direct investments could be measured by the favourable and positive impact on factors or indicators, which include government revenue, employment generation, export earnings, technology transfer and skills training for resident employees as well as multiplier economic effects through service provision to the general public.

According to the literature review findings it could be understood that FDIs were essential for a nation's economic development. A success story of development as a result of FDIs was that of Brazil's economy. In 1969 Zambia's GDP was higher than that of Brazil.

Even the field research indicated that a total of $88 \%$ agreed that FDIs had positive impact on the economy of Zambia in that jobs were created and economy showered some positive improvements in growth:

\section{Benefits of FDIs to ordinary zambians in peri urban and rural areas of operation}

FDIs lead to the establishment of a strong economy, strong corporate profits and cash flow, booming stock market and strong currency in Zambia. That was confirmed by significant growth in real GDP $3.3 \%$ to $5.7 \%$, real GDP per capital (2002) \$316 to \$365 (2007) and reduction in inflation $26.7 \%$ to $8.9 \%$ and bank interest rates $50.0 \%$ to $24.4 \%$ as was indicated during the period from 2002 to 2007 inclusive. (MOF and IMF 2008).

Since the re-introduction of FDIs there had been development of infrastructure like Livingstone Airport, introduction of new technology and new business systems, improvement of communication for example establishment of mobile phone companies like Airtel, MTN and Zamtel, introduction of new culture, to a greater extent creation of employment, recapitalisation of mining companies and the opening of new ones like Lumwana mine. One other important and inevitable factor, which came with the inflow of FDIs, was human capacity building in order to operate new equipment and machinery.

FDIs investment had social implication of increasing employment levels when huge investment was made in the mining sector. Konkola Copper mine had employed up to more than 10,000 employees. That in turn had put money in the pockets of citizens and it had multiplier effect on the economy through increased consumption of goods and services.

Rural Zambians have benefited from FDIs through investments in mining and other sectors that are based in rural areas; FDIs were a catalyst in bringing or reducing illiteracy since to educate children required finances. Also $80 \%$ of the inhabitants on the Copperbelt were employed by the mining sector, 
Konkola Copper Mines being the largest employer in that region of Zambia. Thus, investment through FDIs had been a source of job creation in Zambia.

\section{The Influence of FDIs on culture and society in zambia}

- However, FDIs also had negative impact on developing nations like in Zambia casualisation of the work force, mass redundancies, unsafe working conditions for workers, failure to take on the payment of pension to former employees, contamination of the natural environment and increasing dominance of foreign culture on Zambian culture by those of the investors. Others included manipulation by guest countries of the prices of intra-firm trade by multinational enterprises (MNEs) to reduce their global tax payments.

The pullout of most investors in the mining sector like Konkola Copper Mines' downsizing was a drawback and had a negative effect on the local economy which also resulted in retrenchments of workers hence no income for most of the families and they could not afford health facilities, sending children to school and that also led to some girls turn to prostitution as a means of survival in the mining towns though prostitution was dangerous especially with HIV/AIDS pandemic around.

Other negative characteristics of FDIs included, the fact that Zambia got a raw deal during negotiations under Development Agreements, which resulted in investors being exempted from covering most of ZCCM's liabilities, for example pension provision, passing of labour laws in favour of investors, poor quality in employment in that around $45 \%$ of the workforce in the mines was not on permanent and pensionable contracts, losing of business by local suppliers which they used to conduct with ZCCM and new investors leaving the provision of social infrastructure (schools and hospitals) to the dictates of free-market ideology of those goods and services being provided either by the local authorities or by market forces.

\section{The Contribution of FDIs to trade globalisation with regard to zambia}

- To some extent Foreign Direct Investments had led to the material culture starting to look similar worldwide and national economies merging into interdependent global economic systems. It was one of the systems that had contributed to the reduction in barriers to cross-border trade and investment hence it greatly contributed to trade globalisation. FDIs also endowed a company or country with new markets and marketing channels.

\section{Zambia Shared the Effect of FDIs through involvement in production of components}

that could be used in producing end Products in other Countries: FDIs to some extent brought about similarities in goods produced in developed countries, but that was very minimal in the case of Zambia, because Zambia had not been in the fore front of producing components that could be produced for other countries, not even in the continent, however there was an increase in trade in Zambia with other countries as a result of mining activities in the country. That resulted in huge export earnings, which contributed positively to the economy. That was attributed to Zambia having adopted multi party politics, which brought liberalisation of the economy and opened up doors to foreign investment.

\section{The contributions of foreign direct investments on the Copperbelt}

FDIs presence on the Copperbelt presented empirical evidence of economic growth in the area of operations:

\section{KCM corporate social investments}

Konkola Copper Mines (KCM) strived to ensure that the impact of investment went beyond simply paying taxes, but benefited the communities where they operated.

The Corporate Social Responsibility (CSR) programmes had a rich history. ZCCM-KCM division specifically took on significant social responsibilities from the period before the privatization of the mines, including the development of hospitals, schools and other social programmes. After the acquisition of KCM, the CSR programmes expanded to ensure effective and maximum outreach.

Since 2005, KCM had spent over US\$ 150 million on CSR programmes. The five key areas for social development cover: Health, Education, Sustainable livelihoods, Infrastructure and Sports development: 
- Health: KCM continued to operate two hospitals and eight clinics it inherited prior to Vedanta's acquisition of the mine, providing free medical services to more than 63,000 people annually from across Zambia, including KCM employees and their dependents. It also provided subsidised healthcare to the general public.

Over the years KCM had supported a number of important health initiatives, including:

- Eye Screening Programmes: Between 2008 and 2012, KCM financed eye-screening; provided 15,000 reading glasses to school children and elderly people, and conducted 171 cataract eye operations.

- Artificial Limbs: In 2008, KCM provided 176 amputees in Zambia with artificial limbs.

- Kidney Disease Surgery: Since 2012, KCM supported the first private sector programme bringing permanent access vascular surgery for haemodialysis treatment in Zambia for patients suffering from kidney disease.

- Malaria: Since 2004, KCM supported the Expanded Rollback malaria programme, involving an integrated vector management approach through Indoor Residual Spraying (IRS) of over 40,000 households per year. In the recent times, the programme had moved to provide mosquito nets to households.

- HIV/AIDS: In 2007, KCM launched its workplace HIV/AIDS policy to mitigate effects of HIV/AIDS among employees. Since then, the programme was extended to communities around KCM operation areas.

- Education: When KCM inherited two schools from ZCCM in 2005, it expanded the schools to offer education to more children. KCM extended the two primary schools that it inherited at privatization to full secondary level schools through investment in infrastructure and teaching staff. Previously, the schools accommodated 650 students; however, KCM's investments meant the schools provided education to over 2,000 students. In addition, the top 15-20 students from those schools were sponsored for full-time degree programmes.

Other investments in education included:

- Computer Literacy Programme: Since 2010, KCM provided 410 computers to government run schools, impacting up to 7,000 students. The project was adopted by government as a national policy.

- Nampundwe Primary School: The school, near Lusaka, was converted into a high school and an examination centre. That was achieved through the construction of 10 classroom blocks as well as two science laboratories; doubling enrolment to 1,700 in 2013.

- Classroom Construction: KCM constructed 9 classrooms in 3 government run schools in Chingola in order to create more space for students. Another initiative was to connect a rural school to the national power grid.

- School Hygiene Investments: That included installing boreholes in 10 government run schools, as well as toilet facilities for each school.

- Scholarship Programme: KCM awarded 302 students with scholarships to study in a number of fields, including medicine, mining and business courses in the UK, Australia, India, Namibia, Kenya and Zambia since 2007. That programme covered both employees and their dependents.

- Kitwe Trade School: As one of the largest vocational training centres in Africa, the school provided artisans with skills that were critical for the mining sector. It trained an average of 200 people students each year.

- The day care centres in Chililabombwe and Chingola cater for 320 children of local Marketeers

- The centres provided those children with meals, uniforms and education

- Sustainable development: KCM worked with the local communities to originate sustainable projects that ensured self-sustenance and development beyond the life of the mine. Among those initiatives were:

- Youth Skills Development: KCM supported initiatives for youth skills development through its NGO partners. The programme targeted youths involved in illegal small scale mining by providing training in life skills like tailoring, art, livestock rearing and career guidance for conventional education. 
- Sustainable Livelihoods Programme: In 2012, KCM launched the US\$ 2 million enhanced sustainable livelihood programme, which provided livestock to small scale farmers, particularly to women and youth. Beneficiaries were imparted with farming knowledge and the programmes helped with income generation, a reduction of poverty and enhanced food security.

- Infrastructure: In 2012, KCM invested in road infrastructure, reconstructing 7.5 kilometres of road network in Chingola and targeting roads leading to densely populated areas at a cost of US\$ 4.5 million.

- Sports Development: KCM has been the largest sponsor of football in Zambia, and was the only privately owned firm that supported four teams in the top leagues of the Football Association of Zambia (FAZ). The teams supported in the league were: Nchanga Rangers; Konkola Blades; Konkola Mine Police and Nampundwe FC.

Football was not simply important as a sport in Zambia, but it also provided an alternative source of livelihood for thousands of young footballers and support staff. Teams provided employment to 160 young talents. Those four KCM teams provided 10 players to various junior and senior national football teams. In addition, two coaches from the KCM clubs were appointed to train Zambia's national youth teams.

Other football support and sponsorship initiatives have included:

- FAZ Leagues: KCM pioneered the private sector sponsorship of all structures in the FAZ leagues from 2005 to 2011. The support to the FAZ league was comprised of financial support to all registered teams, footballs and the use of two KCM stadiums to the Zambian national team.

- African Cup of Nations: In 2012, Zambia won Africa's premier football event, the African Cup of Nations (Afcon). In celebration of the achievement, KCM chartered a Boeing 737 aircraft to carry supporters from Zambia to Gabon and back to Zambia, accompanied by the victorious national soccer team. Key to that success was the holistic approach taken to support the FAZ league, the hiring of specialist coaches, and the sponsorship of four teams in the league.

Football was not the only sport that KCM supported:

- KCM also provided Platinum sponsorship of the Zambia Open golf championship - a fixture in the Sunshine Tour - in both 2011 and 2012.

- In 2012, the company also provided a US\$2 million upgrade of the Nchanga golf course restoring it to its former glory - the club was ranked 14th best outside the USA in 1979. (Source: CSR of $\mathrm{KCM}$ )

\section{Conclusions on the findings}

The sampled investors in the FDIs survey were satisfied with the investment climate in Zambia with a significant number of them ranking the various factors of taxation system, employment registration, legal system and investment regulations, effectiveness and usefulness of government institutions charged with facilities and regulations of the investments process as either good or fair. $77 \%$ of the respondents indicated that they expected Zambian's economic future to be bright.

However, there was considerable dissatisfaction in some spheres in both areas of government policies and efficiency of institution that played key roles in the investment facilitation. Much more needed to be done to ensure a bright economic future. There was need for consistency in policies, particularly tax policies and the need to ensure professionalism in institutions that played investment facilitation roles in the investment process. There was also need to ensure that the investment policies benefited the local investors as well.

The overall survey reflected a general positive impact to the domestic economy by the major economic factors analyzed in the study. FDIs had created employment at Konkola Copper Mines of more than 10,000 workers. That in turn had put money in the pockets of citizens and it had multiplier effect on the economy through increased consumption of goods and services leading to alleviation of poverty to some extent of people living in Chingola. Jobs were created through factories and companies that worked in collaboration with Konkola Copper Mines. Jobs were also created through contracting workers though their wages were lower compared to those that worked directly under Konkola Copper Mine. 
Foreign direct investment in Zambia helped to create linkages between local and foreign investors to a smaller extent. Linkages created channels through which skills, knowledge and technology from foreign firms diffused into local firms was achieved but not in trade, KCM procured mainly from abroad.

Political stability was one of the most important motivating factors to investors for choosing to invest in Zambia. Other factors were macroeconomic situation and the market size. Factors such as raw materials, cheap labour and production costs were of secondary importance overall. Stock market was another important investment factor. Additionally, another investment factor was Zambia's geographical strategic location as it offered access to markets in neighbouring countries. Thus, being land linked as opposed to land locked thought before.

The process of investors taking over Konkola Copper Mine appeared not to have been done in good faith especially where employees were concerned. Employees knew that working conditions were not the same as they were under ZCCM. That pointed to failure by both investors and government to handle the transition professionally. It seemed there was failure in managing change from ZCCM situation to the privatisation of Konkola Copper Mine to Vedanta Resource Plc led private hands.

\section{Implications and recommendations}

When the mining industry is functioning to the full capacity the gains that are possible for all are enormous. In the past miners were able to get sufficient wages to support their families and possibly plan for a small business which they could develop with their pension upon retirement.

The miners who were still working after privatization lived in poverty, they were not able to feed and clothe their families and they were fearful of how they would survive their retirement without a pension. By then the government and the mining companies seemed not to have been accepted by the mining community.

The evidence gathered from the report (Fraser and Lungu, 2011), suggested that well-founded popular complaints about the mining industry were based on bread and butter issues which included poverty wages, insecure terms and conditions, resistance to legal right of trade unions, inadequate support for retrenched and retired workers and a failure of attention to safety measures and environment protection by the new mining companies. The government might need to break free of the obsession with 'investor-friendly policies' and use their regulatory and legal powers to prioritise the need and rights of workers and communities

\section{Proposed FDIs Mining Sector Implementation Model for Zambia (The JCP Model)}

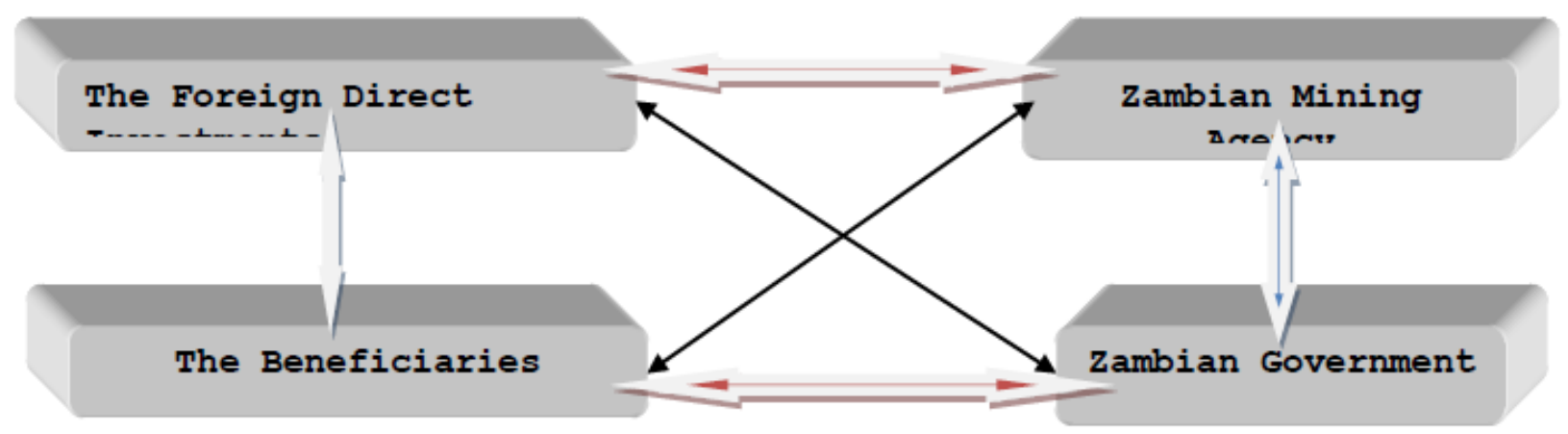

Source: The author 2018

For Zambia to gain maximum benefits from its natural resources, there would be need to establish a clear relationship of the diamond nature other than the triangle nature which existed at the time of the study. As shown by the above model, an introduction of an agency specialised in the mining sector for policing the regulation of the mines, assessing and collection of the revenues from the mines in form of royalties and taxes. That is required because Zambia Revenue Authority (ZRA) has no capacity to adequately address the issues of revenue collections from the mines. Such an agency is to have mining experts capable of assessing the revenues from the mines and then tax the companies according. The proposed Agency would relieve the pressure from ZRA and allow the government to concentrate on policy issues and creation of the 'enabling environment' in the mining sector. 
Other roles of Zambia Mining Agency (ZMA) would extend from implementing government policies to ensuring that the local businesses and communities' benefits from the FDIs' areas of operations by creating business linkages and demanding adequate social investments in all social sector of the communities.

\section{Reference}

[1]. Bannock G. et al, (2004), Dictionary of Business, The Economist, Penguin Books, Kundli, New Delhi

[2]. Belda P. (2006), eBizguides Zambia, The Premier Guidebook for Business Globetrotters, World Investment News Inc, Geneva,

[3]. Bridges W. (1991), Managing transitions: making the most of change, Wesley Publishing Company, Reading, MA

[4]. Brooks I. et al, (2000), The Business Environment, ( $2^{\text {nd }}$ ed), Pearson Education Ltd., London,

[5]. Cambridge (2005), Advanced Learner's Dictionary, ( ${ }^{\text {nd }}$ ed), Cambridge University Press, London

[6]. Cole G.A. (2004), Strategic Management, ( $2^{\text {nd }}$ ed) Ashford Colour Press, London,

[7]. Cole G. A. (2004), Management Theory and Practice, ( $6^{\text {th }}$ ed), Thomson Learning, London,

[8]. Collin P. H. (2006), Dictionary of Business, ( ${ }^{\text {th }}$ ed), A \& C Black London, United Kingdom

[9]. Cooper D. R. et al, (2006), Business Research Methods, (9 ${ }^{\text {th }}$ ed), MacGraw-Hill International Edition, Singapore

[10]. De Jager P. (2001, May/June), Resistance to change, anew view of an old problem, The futurist 24-27

[11]. Folger, R. \& Skarlicki, D. (1999). Unfairness and resistance to change: hardship as mistreatment, Journal of Organisational Change Management

[12]. Fraser A. et al, (2011) For whom the windfalls (Winners and losers in the privatisation of Zambia's copper mines), Aquila Printers Ltd, Lusaka

[13]. Goldin I and Reinert K, (2006), Globalisation for development, The World Bank, 1818 h Street NW, Washington, DC 20433,

[14]. Hill C. W. L. et al, (2007), International Business, (5 ${ }^{\text {th }}$ Ed.) Tata MacGraw Publishing Company Ltd, New Delhi,

[15]. Ian G. et al, (2006), Globalisation for Development, Palgrave Macmillan, New York,

[16]. Johnson G. et al, (2006), Exploring Corporate Strategy, (6 ${ }^{\text {th }}$ ed), Dorling Kindersley, New Delhi

[17]. Jones N. R. (2003), Managing change, (4th ed) Management Pocket Books Ltd, London, U

[18]. Kothari, C. R. (2012) Research Methodology: Methods and Techniques $2^{\text {nd }}$ edition, New Age International Publishers, New Delhi:

[19]. Kumar, R. (2009) Research Methodology: A step by Step Guide for Beginners, SAGE Publication, London.

[20]. Lynch R. (2006), Corporate Strategy, ( ${ }^{\text {th }}$ ed), Prentice Hall, Essex, London, England

[21]. Morrison J. (2006), The international Business Environment, ( $2^{\text {nd }}$ ed.), Palgrave Macmillan, New York, United States of America

[22]. Movement for Multiparty Democracy National Campaign Committee, Movement for Multiparty Democracy Manifesto (2007 - 2011), New Horizon Printing Press

[23]. Marczyk, G., DeMatteo, D., Festinger, D. (2005) Essentials of Research Design and Methodology, John Wiley \& Sons Inc, New Jersey.

[24]. Mercy Corps 2007, 'Foreign Investment for Poverty Reduction in Africa', Article on FDIs.

[25]. Palmer I. et al (2006), Managing Organisation Change, A multiple Perspective Approach, McGraw-hill, Boston, USA

[26]. Ortega E. (2005), World Bank Mission Report No. 3 Seed Project, Lusaka,

[27]. Saunders, M., Lewis, P., Thornhill, A. (2012) Research Methods for Business Students 6th edition, Pearson Education Ltd, Harlow.

[28]. Singh, Y. K. (2006) Fundamentals of Research Methodology and Statistics, New Age International Publishers, New Delhi

[29]. Sutherland J. et al, (2004), Key Concepts in Operations Management, Palgrave Key Concepts, Macmillan, Shanghai

[30]. Sutherland J. et al, (2004), Key Concepts in Marketing, Palgrave Key Concepts, Macmillan, Hampshire,

[31]. The Private Sector Development Forum, July, 2004, 'Creating the right environment for a vibrant private sector' 
[32]. Velasquez M. G. (2002), Business Ethics, (5 ${ }^{\text {th }}$ ed), Asoke K. Ghosh, Prentice-Hall, New Delhi,

[33]. Wikipedia 2009, 'Foreign direct investment', article on FDIs.

[34]. www. Bloomberg .com, 2009, 'Brazil's FDI surged in December 2008', article on FDIs.

[35]. Yin, R.K. (2003) Case Study Research: Design and Method $3^{\text {rd }}$ edition. Sage, London.

[36]. Zambia Demographic and Health Survey, (2007), Calverton, Maryland, USA: Central Statistics Office and Macro International Inc.

[37]. Zambia Development Agency (January 2014) Public-Private-Partnerships in Infrastructure Development in Zambia; ZDA, Lusaka

[38]. Zambia Development Agency (2012), Report on the Economic Impact of Direct Investment on the Zambian Economy:

[39]. Zambia Development Agency, Enhancing Zambia Development Agency's Capacity to Facilitate Investors and Investment Journal: Investment promotion

[40]. Huse, M, D \& Muyakwa S, L 2007, 'China in Africa', Lending, policy space and governance.

[41]. United Nations \& Ministry of Commerce, Trade and Industry, 2006, 'An investment guide to Zambia' Opportunities and conditions.

[42]. http://kcm.co.zm/our-commitment-to-zambia/corporate-social investments/\#sthash.i9qNb7q4.dpuf

[43]. (http://kcm.co.zm/corporate-profile/\#sthash.9s1R3WLT.dpuf). 